Sustainable Practices in Furniture Design: Can Green Practices Influence Competitiveness?

David L. Nicholls, Research Forest Products Technologist, Pacific Northwest Research Station, Juneau, AK

david.I.nicholls@usda.gov

Matthew S. Bumgardner, Research Forest Products

Technologist, Northern Research Station, Delaware, $\mathrm{OH}$

\section{Carbon Sequestration in Furniture}

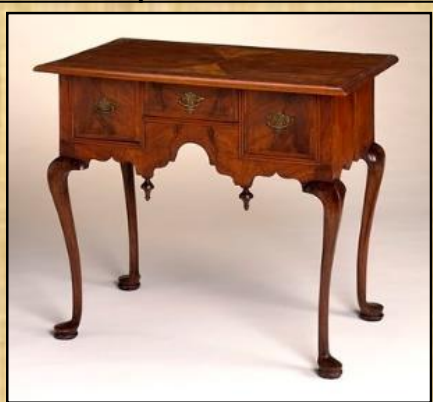

Figure 1. Furniture products have been sequestering carbon for centuries. An example is this
lonial era dressing table constructed in the mid-17 700 s. Wood products that are sufficiently dry well-preserved (and well designed) are capable of lasting centuries with essentially no hange (Photo
source: https://study.com/academy/lesson/colonial-furniture-history-characteristitics.html)

Embedded Biomimicry Designs

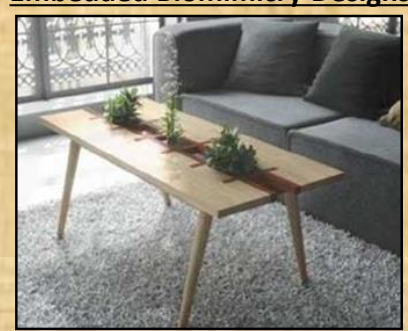

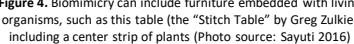

\section{References}

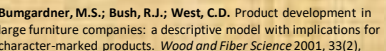
character-m
302-313.

European Comm
www.ecolabel.eu

Knight, $p$; J Jenkins, J.I. Adopting and applying eco-design
techniques: a practitioners perspective. Journal of fleaner

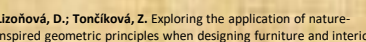

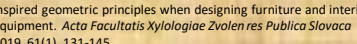

\section{Green Manufacturing and Supply Chain}

Product design can be an important enabler of sustainable supply chain mgt.

- Eco-design extends traditional design (Fig. 2) Eco-design principles include: -use of recycled materials -low energy consumption -reduced product weight -less waste during manufacture -greater use of reusable packaging -longer life-spans

\section{Biomimicry in Furniture Design}

Often mimic plant structures (rather than animals or insects)

- Furniture designs can include living organisms within the product (Fig. 4)

- Contemporary designs often preferred to traditional designs

- Driven by high level of innovative design, leading to low environmental footprints and aesthetic appeal

- Wood and and fabrics often the preferred materials

- Biomimicry is still very much an evolving field for furniture design

urniture represents a significant component of hardwood utilization and production internationally, and sustainable design practices are becoming more widespread in response to increased consumer demand for green products. In this research, we consider ecosystem services - the benefits people derive from ecosystems - from a secondary wood products perspective. We review and fynthesize the literature surrounding the design, use, and disposition of wood for green practices in design and associated communications with consumers.

\section{Ecodesign vs. Traditional Design}

ECO-DESIGN

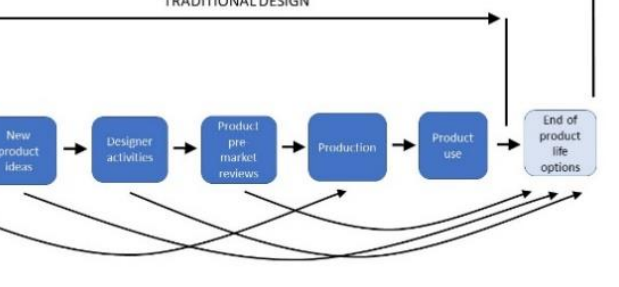

2. A conceptual model of traditional and eco-design processes for furniture product

\section{Results and Discussion}

Drivers of Sustainable Design

Green manufacturing becoming increasingly important in effective marketing

Small firms can use sustainable design strategies to become globally competitive

Effective eco-design often requires commitment early in product design process

Role of designers can vary from firm to firm

Furniture Design -Vertical Supply Chain Considerations

- Standard-driven greening (design plays a key role) Mentor-driven greening (relationships and interaction based)- environmental impact reduced due to flexibility and innovation

Retailers communicate environmental initiatives to consumers

Retail buyers use different cues that manufacturing personnel (supply chain challenges)

Marketing Sustainable Design - Green Communication - European eco-labels for flooring and furniture - Ecolabels can increase consumer confidence

Effective ecolabels are simple- use fewer materials, have shorter supply chains, favor solid wood Effective ecolabels should evoke an emotional connection with potential customers (Fig. 5)
Reviewed literature regarding ecosystem services derived from furniture design and manufacture, focusing on the influence of design on product competitiveness

Included key terms green manufacturing, green supply chains, eco-design, sustainable materials, biomimicry, and eco-labeling

Literature search carried out using Google Scholar in early 2020 Other articles based on cross-referencing/author knowledge (79 articles included) Most papers based on research conducted in N. America, Europe, and Asia

Biomimicry in Chair Design

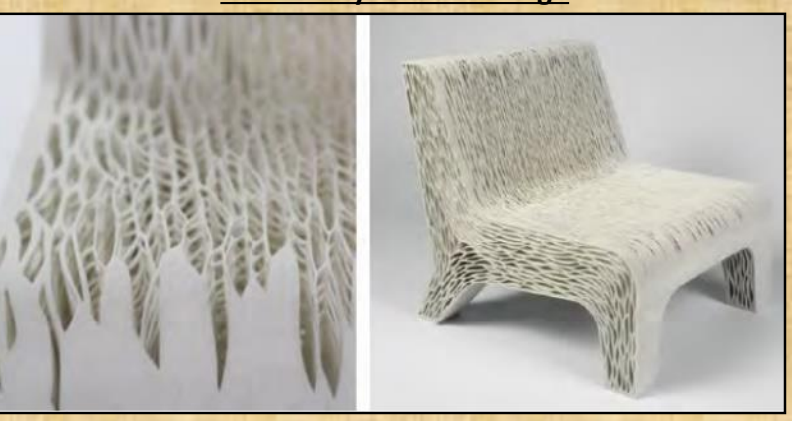

Figure 3. Biomimicry principles in chair design by Lilian Van Daal. The plant cell structure enhances not only appearance but also structural attributes of the soft
Toncikova 2019)

Ecolabels (Floors \& Furniture Example)

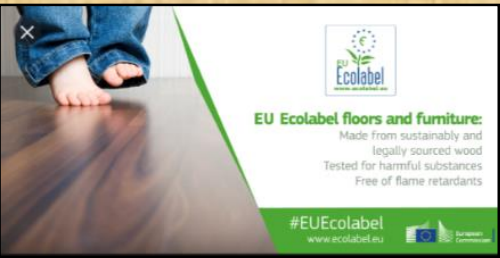
Figure 5. EU ecolabel for floors and furniture, providing product detal
and emotional connection to consumers (Source: www.ecolabel.eu)

\section{Conclusions}

Sustainable design can help competitiveness -well designed / emotionally appealing -longer lifespans can lead to greater environmental benefits

Designers can work directly with consumers (make-to-order)

- Designers can help create computer programs for consumers to rapidly customize furniture

- Sustainable design is most effective when companies commit early in product development

- Sustainable design drivers can be market-based and/or regulation-based

Creativity and imagination is key to successful design of high value hardwoods 